\title{
QUALITY COMPLIANCE AND ENVIRONMENTAL IMPACT ASSESSMENT OF COMMERCIAL EMPTY FRUIT BUNCH (EFB) PELLET FUEL IN MALAYSIA
}

\author{
NASRIN, A B*; VIJAYA, $S^{*}$; LOH, S K*; ASTIMAR, A $A^{*}$ and LIM, W $S^{\star \star}$
}

\begin{abstract}
Empty fruit bunch (EFB) is a potential feedstock for the commercial production of biomass pellet fuel. In this study, the fuel properties of EFB pellets collected from four production plants were examined and the impacts of pellets production to the environment were determined using Life Cycle Assessment (LCA) approach. The fuel properties concerning moisture and energy content, bulk density and durability index were comparable to the European Standard (EN 14961-2) for solid biofuels except for the higher ash content i.e. $>6 \%$. This high ash content contributed to the low energy content of the pellets. This was caused by contamination from soil and dirt, attributed due to poor handling of the raw material. The EFB pellets contained a high concentration of potassium, nitrogen, chlorine and sulphur compared to wood-based pellets. The presence of these elements affected biomass combustion at the furnace as well as emission generation. The Life Cycle Impact Assessment (LCIA) carried out showed that the main environmental impacts of the production of EFB pellets were fossil depletion, climate change and particulate matters emission. This was due to the plants' heavy dependence on the grid-connected electricity. The results can be used to identify approaches in upgrading EFB pellets quality and reducing the associated environmental impacts.
\end{abstract}

Keywords: empty fruit bunch, palm pellet, fuel characteristics, life cycle analysis, environmental profile.

Date received: 10 April 2017; Sent for revision: 11 April 2017; Received in final form: 31 July 2017 ; Accepted: 11 August 2017.

\section{INTRODUCTION}

The utilisation of renewable energy (RE) resources as an alternative energy is an important element in the national policy of many countries in the world. Factors such as unpredictable supply, demand and price of fossil-based energy, and its associated environmental issues have increased the interests to consider alternative and clean energy. Demand for

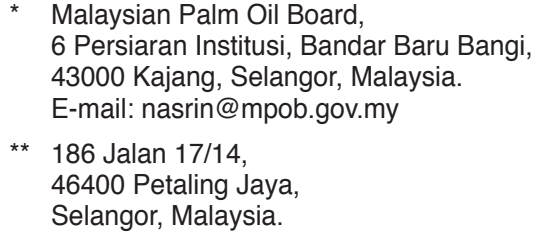

$\mathrm{RE}$ is growing, in particular the biomass energy in the form of solid biofuel. This is to safeguard energy security and enhance fuel diversification. According to the International Energy Agency (IEA), biomass is the largest RE used today, contributing to about $10 \%$ of the world's primary energy supply (IEA, 2016).

As the world's second largest palm oil producer, Malaysia is blessed with an abundance of biomass, mainly generated from the oil palm plantations and the palm oil milling process. Assuming that the weight ratio (wt/wt, \%) of mesocarp fibre, palm shell and empty fruit bunch (EFB) to fresh fruit bunch (FFB) is $13 \%, 6 \%$ and $23 \%$, respectively, the total solid biomass generated from all palm oil mills (453) alone in Malaysia was 36.05 million tonnes (wet basis) based on 85.84 million tonnes FFB processed 
in 2016 (Kong et al., 2014; MPOB, 2017). These resources have been used as fuel either for domestic consumption in palm oil mills, industrial sector or grid-connected biomass power plant. Recently, oil palm biomass, particularly EFB has been identified for use as a raw material for the production of pellets or briquettes as a solid biofuel.

Pellet is an upgraded form of biomass fuel mainly made from wood or agriculture waste through the densification of loose biomass. It has long been used for heat and electricity generation for residential, commercial and industry uses. Recently, biomass pellets have been used commercially by some of the developed countries for co-firing with coal or as a sole fuel for electricity generation. The production and consumption of biomass pellets have increased significantly since 2008. According to Matthews (2015), the global biomass pellet production from wood was 28 million tonnes in 2015 (Figure 1). Seventy-five percent of the world's wood pellets were consumed by European countries, followed by North America (14.3\%) and Asian countries, mainly South Korea and Japan (7\%) (Murray, 2016). The world's pellets demand is projected to grow to 50 million tonnes in 2024 (Walker, 2014).

In producing palm biomass solid biofuel from EFB, two main processes are involved; namely the pre-treatment of raw EFB followed by the compacting process. This approachreduces moisture, increases the bulk and energy density, enables easy transportation and logistics as compared to its raw material, thus expanding the use and marketability of EFB as uniform solid fuel (Kylili et al., 2016). The potential and characteristics of EFB pellets have been studied by many researchers (Erlich and Fransson, 2011; Rahman et al., 2013; Lam et al., 2014; Munawar and Subiyanto, 2014). However, most of these studies focused only on the EFB pellets production and quality characterisation at the research and development (R\&D) stage with scarce information on commercial production, EFB pellets specification and the resulting environmental impacts. One of the accepted methods to quantify such environmental impact and outputs of a product is the Life Cycle Assessment (LCA) (Vijaya et al., 2008; Reed et al., 2012). It is also known as one of the principal decision support tools to assess the flow dynamics of resources.

By using LCA, the environmental impacts of the technology used and the production process for oil palm solid biofuel can be evaluated. The impacts are not only associated with the biofuel production, but also with the transportation of the feedstock and product as well as the greenhouse gases (GHG) emissions from solid biofuel burning (Magelli et al., 2009). All these will determine whether the oil palm biomass utilisation via solid biofuel production is environmentally sustainable to the oil palm industry and its potential users. Hence, this study aimed to determine the properties of EFB pellet produced from commercial plants and to develop primary data to evaluate and address the environmental impact of EFB pellets production from different production approaches using the LCA tool.

\section{MATERIALS AND METHOD}

\section{Analysis of EFB Pellets}

The pellets were collected from four production plants located in Peninsular Malaysia. The samples

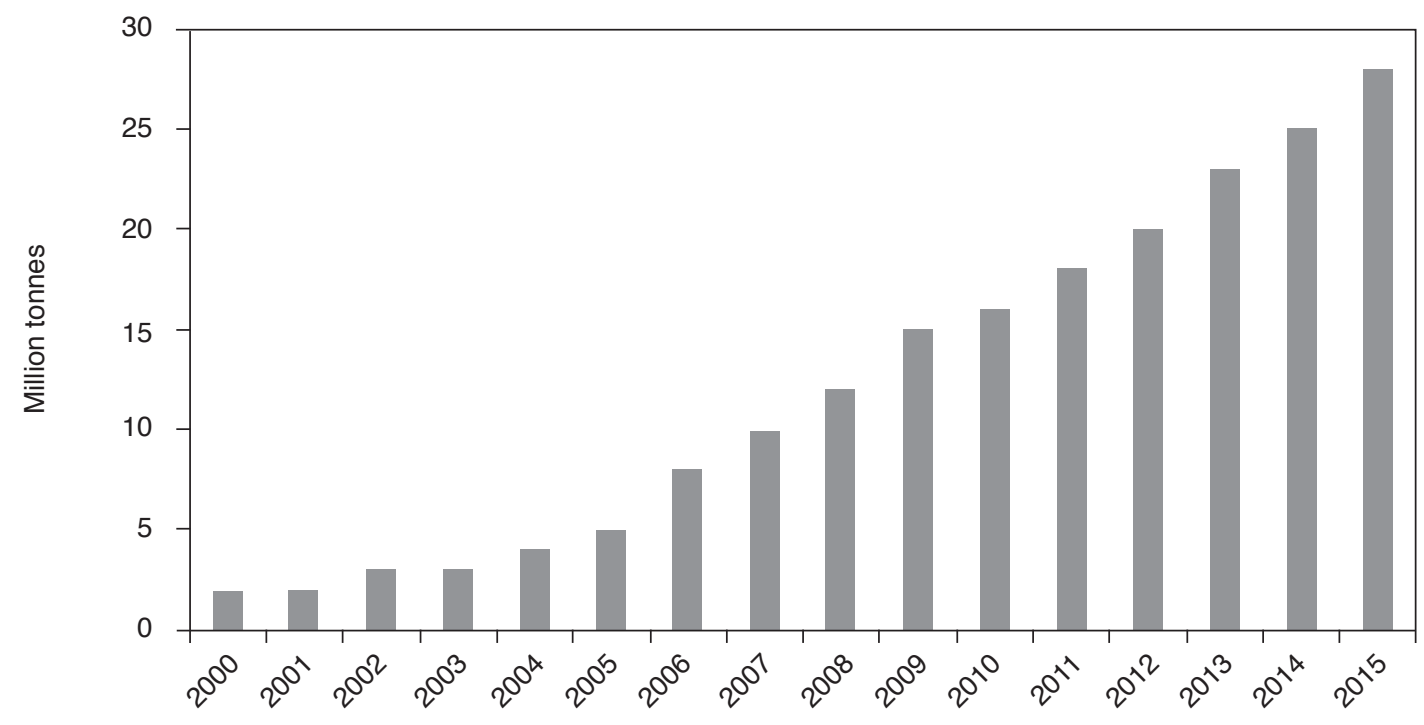

Figure 1. Global wood pellet production 2000-2015 (Matthews, 2015). 
obtained were randomly selected and analysed for their physical and chemical properties, and elemental content according to standard test methods (Table 1). The diameter and length of the pellets were determined according to EN 14127 using a digital caliper (Mitutoyo CD-20APX). The gross calorific value $(\mathrm{CV})$ was determined using an isoperobolic system bomb calorimeter (LECO AC 600) based on ASTM D5865-07. Analysis of moisture content (MC), ash content, volatile matter (VM) and fixed carbon (FC), i.e. the proximate analysis was carried out using a thermogravimetric analyser (LECO TGA 701) according to ASTM 5142. The FC was calculated by subtracting the percentage of the sum of VM, $\mathrm{MC}$ and ash content from the sample (Acda and Devera, 2014). The ultimate analysis to determine carbon (C), hydrogen (H), nitrogen (N) and sulphur (S) was performed according to ASTM D5373 using a CHNS analyser (LECO CHNS 628). The concentration of oxygen $(\mathrm{O})$ was calculated by difference between $100 \%$ and the sum of C, H, $\mathrm{N}$ and $\mathrm{S}$.

The concentrations of trace elements focusing on alkaline metals [e.g. phosphorus $(\mathrm{P})$, potassium $(\mathrm{K})$, calcium $(\mathrm{Ca})$, and magnesium $(\mathrm{Mg})]$ and chlorine $(\mathrm{Cl})$ were determined using a flame atomic absorption (AAS) (Perkin Elmer Analyst 400) and a scanning electron microscopy energy dispersive X-ray (SEM-EDX) (Hitachi Bruker), respectively. The density kit (Mettler Toledo ML-DNY 43) was used to determine the density of the pellets. The bulk density of the pellets was determined according to EN 1097-3 as described by Theerarattananoon et al. (2011). Holmen pellet durability tester (NHP 100) was used to determine the pellet durability (PD) in accordance to EN14961-2. Durability is defined as the ability of the pellets to withstand destructive loads and force, in particular during pellet transportation (Theerarattananoon et al., 2011). All the analyses were performed in triplicate. The results were compared to the European (EN 14961-2) and International Standard (ISO 17225-6) on wood and non-wood pellets.

\section{LCA Study}

A gate-to-gate assessment using LCA approach was performed on the production of EFB pellets for four commercial plants. The starting point of the system boundary was at the receiving yard of the production plant where the feedstock i.e. EFB was received. The end point was after the production of pellets. The functional unit of this study was $1 \mathrm{t}$ solid biofuel produced. Questionnaires were prepared and sent to the four EFB pellet producers for data acquisition and site visits were conducted for data verification. The data required were raw material usage, production quantity, diesel fuel for internal vehicle, electricity consumption, and biomass fuel or steam for drying purpose.

The data obtained were used to establish a Life Cycle Inventory (LCI) for the assessment of Life Cycle Impact (LCIA) using the RECIPE Methodology of Simapro Software version 8.0.4. The LCA was used to identify the environmental impact, GHG emissions and establish baseline information and database for a comprehensive assessment of the environmental and energy profile of the EFB pellets production. The GHG emissions from electricity and diesel usage were determined using the global warming potential (GWP) and emission factors (EF) provided by the Wisions Sustainable Energy Project Support programme (SEPS). The EF for electricity and diesel were $0.000594 \mathrm{tCO}_{2} \mathrm{eq} \mathrm{kWhr}^{-1}$ and 0.00268 $\mathrm{t} \mathrm{CO}_{2}$ eq litre ${ }^{-1}$, respectively (Vijaya et al., 2010).

\section{RESULTS AND DISCUSSION}

\section{Characterisation of EFB Pellets}

EFB pellets obtained from the four production plants were produced using a ring die technology with $8 \mathrm{~mm}$ die diameter. The pellets were relatively uniform in size with their length (L) and diameter (D) being within the acceptable range as required by the EN 14961-2 and the proposed ISO 17225-6 (D: $8.0 \pm 1.0 \mathrm{~mm}, \mathrm{~L}: 31.5<\mathrm{L}<40.0 \mathrm{~mm}$ ) (Table 2). On

TABLE 1. ANALYSIS OF PHYSICO-CHEMICAL AND MECHANICAL PROPERTIES OF EMPTY FRUIT BUNCH (EFB) PELLETS

\begin{tabular}{lll}
\hline Analysis & Standard method & Equipment \\
\hline Diameter and length & EN 14127 & Digital caliper - Mitutoyo CD-2APX \\
Calorific value & ASTM D5865 & LECO AC 600 \\
Proximate analysis & ASTM 5142 & LECO TGA 701 \\
Ultimate analysis & ASTM D5373 & LECO CHNS 628 \\
Elemental analysis & SEM EDX & Hitachi - Bruker \\
& AAS & Perkin Elmer Aanalyst 400 \\
Specific density & ASTM D792-08 & Mettler Teledo ML-DNY 43 \\
Bulk density & EN 1097-3 & 5-litre cylinder container \\
Durability & EN 14961-2 & NHP Holmen \\
\hline
\end{tabular}


average, the $\mathrm{L}$ and $\mathrm{D}$ of the EFB pellets were 35.75 $\mathrm{mm}$ and $8.33 \mathrm{~mm}$, respectively. Table 2 also shows that the bulk density of all the EFB pellets fullfilled the requirement of both standards, except for those from plant $\mathrm{D}$ which was $<600 \mathrm{~kg} \mathrm{~m}^{-3}$. Factors such as high MC and non-homogenous size of the feedstock may influence the pelletising process thus affecting the bulk density of the resulting pellets. Probably, the use of raw EFB as the feedstock with deteriotrated property in plant $\mathrm{D}$ compared to other plants which used either pressed or shredded EFB had resulted in a lower bulk density. Nevertheless, the pelletising process somehow managed to increase the bulk density of all the EFB pellets compared to its typical $<200 \mathrm{~kg} \mathrm{~m}^{-3}$ for the raw biomass (Stelte et al., 2011; Nunez et al., 2012). Besides improving the energy density, high bulk density also facilitates the logistics and trading aspects of the pellets, in particular during transportation and storage either for both the producers or users (Acda and Devera, 2014). The specific density of the EFB pellets was also comparable to the typical density value of biomass pellets (Stelte et al., 2011).
The proximate analysis and $\mathrm{CV}$ of the EFB pellets are summarised in Figure 2. On average, the results showed that the EFB pellets had comparable moisture and $\mathrm{CV}$ to that of wood pellets stipulated in the EN 14961-2 except for a higher ash content i.e. $>6 \mathrm{wt} . \%$ (Table 3). The high ash content, in particular those from plants A and B was probably caused by the contamination with soil and dirt due to the poor handling of the raw material either at the palm oil mills or the pellet production plant, as well as during the transportation of the material to the production plant. The treated EFB was also temporarily stored on the ground at open space prior to delivery to the production plant for processing. A higher ash content of the EFB fuel may contribute to lower $\mathrm{CV}$ of the pellets as ash is an incombustible matter which will not contribute to heat release during the combustion process (Chin et al., 2013; Loh, 2017). Ash content can be reduced through pre-screening of the feedstock prior to pre-treatment and pelletising process or if the production plant is within a palm oil mill complex. Raw material pre-screening has been implemented in plant $\mathrm{C}$ meanwhile plant $\mathrm{D}$ is

TABLE 2. PHYSICAL PROPERTIES OF EMPTY FRUIT BUNCH (EFB) PELLETS

\begin{tabular}{|c|c|c|c|c|c|}
\hline Source of pellet & $\begin{array}{l}\text { Weight } \\
\text { (g) }\end{array}$ & $\begin{array}{c}\text { Diameter (D) } \\
(\mathrm{mm})\end{array}$ & $\begin{array}{l}\text { Length (L) } \\
(\mathrm{mm})\end{array}$ & $\begin{array}{l}\text { Bulk density } \\
\quad\left(\mathrm{kg} \mathrm{m}^{-3}\right)\end{array}$ & $\begin{array}{c}\text { Specific density } \\
\left(\mathrm{kg} \mathrm{m}^{-3}\right)\end{array}$ \\
\hline Plant A & $2.10 \pm 0.40$ & $8.23 \pm 0.06$ & $37.33 \pm 6.35$ & $646.0 \pm 0.23$ & $1324.33 \pm 1.53$ \\
\hline Plant C & $2.93 \pm 0.19$ & $8.45 \pm 0.06$ & $40.33 \pm 4.16$ & $664.0 \pm 8.00$ & $1302.30 \pm 8.96$ \\
\hline Plant D & $1.93 \pm 0.25$ & $8.27 \pm 0.06$ & $33.67 \pm 1.53$ & $524.3 \pm 1.25$ & $1239.50 \pm 8.23$ \\
\hline EN 14961-2 (wood) & - & $8 \pm 1$ & $3.15 \leq \mathrm{L} \leq 40$ & $>600$ & - \\
\hline $\begin{array}{l}\text { ISO } 17225-6 \\
\text { (non-wood) }\end{array}$ & - & $8 \pm 1$ & $3.15 \leq \mathrm{L} \leq 40$ & $>600$ & - \\
\hline
\end{tabular}

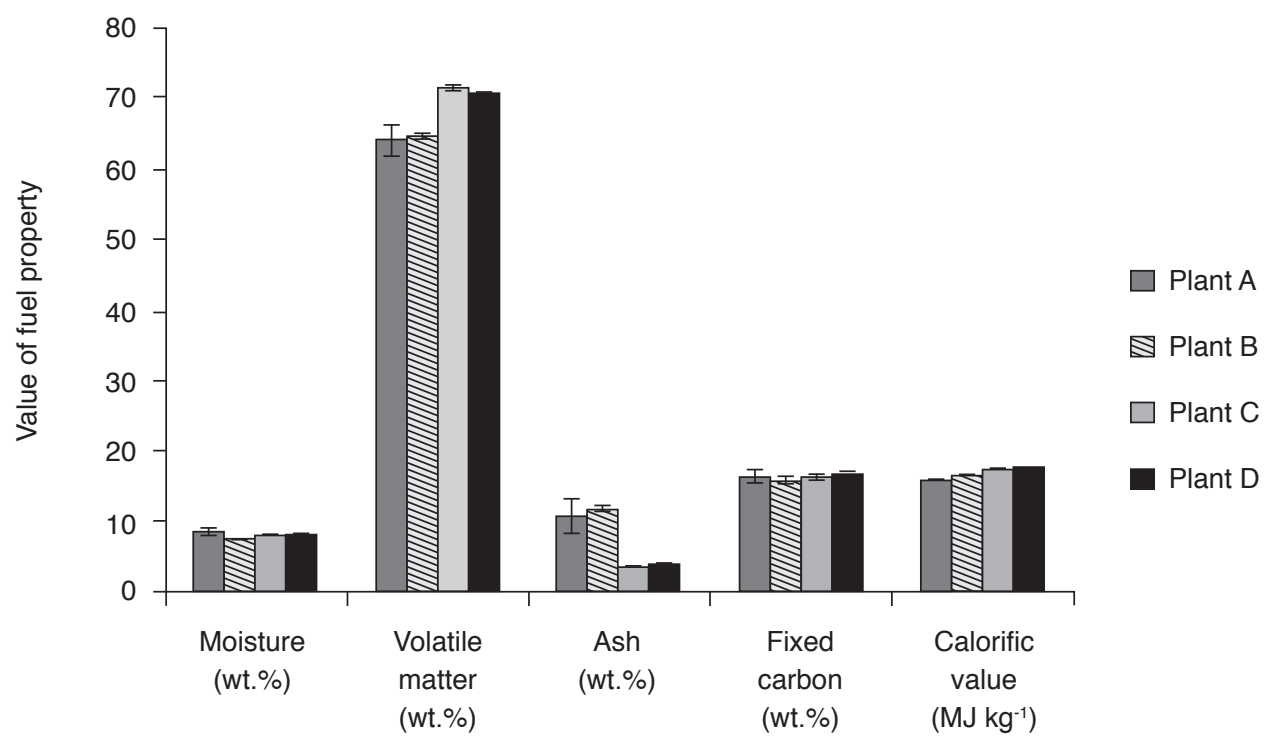

Figure 2. Proximate analysis of empty fruit bunch (EFB) pellets. 
integrated with a palm oil mill; thus the pellets from both the plants showed mean values of ash content $<4$ wt. $\%$.

Besides the ash content, the MC could also influence the $\mathrm{CV}$. In general, the findings indicated lower $\mathrm{CV}$ of the produced EFB pellets with higher $\mathrm{MC}$ and thus, would affect the combustion efficiency as heat is mainly used to evaporate the water during the initial stage of combustion (Chin et al., 2013). Nevertheless, pelletising of EFB had significantly reduced the $\mathrm{MC}$ from $>65 \mathrm{wt} . \%$ in the raw $\mathrm{EFB}$ to $<9$ wt.\% (Loh, 2017). Though not specified by both the EN 14961-2 and ISO 17225-6, the VM and FC of the produced EFB pellets were reported in Figure 2 and Table 3 as these two are among the important combustion parameters. The VM of EFB pellets (64 - 72 wt. $\%$ ) was quite similar to that of wood pellets (72 - 85 wt.\%) but was much higher compared to coal e.g. 35 - 40 wt.\% (McKendry, 2002; Mitchell et al., 2016). According to Loh (2017) and Mckendry (2002), this range of VM facilitates ignition and makes subsequent combustion process better for biomass fuel than coal.

As shown in Figure 3 and Table 4, the major constituents of EFB pellets were $\mathrm{O}, \mathrm{C}$ and to a limited extent, $\mathrm{H}$, making up >95 wt. $\%$. These elements, particularly $\mathrm{C}$ and $\mathrm{H}$ have positive effect on $\mathrm{CV}$ (Obernberger et al., 2006; Loh, 2017). The C content in EFB pellets was lower than wood-based pellets, thus reflecting the lower CV of EFB pellets compared to its wood counterpart (Erlich and Fransson, 2011; Acda and Devera, 2014). The $\mathrm{N}$ and S contents of a fuel give rise to undesirable emissions i.e. $\mathrm{NO}_{\mathrm{x}}$ and $\mathrm{SO}_{x}$ during the thermal processes. The $\mathrm{N}$ content in the produced EFB pellets ranged 0.24 - 0.95 wt.\% i.e. within the acceptable level stipulated in the EN 14961-2 ( $\leq 1.0$ wt.\%) and ISO 17225-6 (<2.0 wt.\%). On average, the $S$ was relatively higher compared to wood pellets standard, i.e. $>0.08 \mathrm{wt} . \%$ but still within the limits set under the proposed ISO 172256 for non-wood pellets (Table 4). Nevertheless, the $\mathrm{N}$ and $\mathrm{S}$ contents are generally considered very low among the biomass fuels, and if at all emitted during combustion, would be minimal or even negligible (Acda and Devera, 2014; Loh, 2017).

This study also indicated that EFB pellets contained higher $\mathrm{Cl}$ and alkaline metals. The $\mathrm{Cl}$ content (0.6 wt.\%) was higher compared to the required EN 14961-2 ( $\leq 0.03$ wt. $\%)$ and ISO 17225$6(\leq 0.5$ wt. $\%)$ specifications. The alkaline metals

TABLE 3. COMPARISON OF PROXIMATE COMPOSITIONS OF EMPTY FRUIT BUNCH (EFB) PELLETS WITH SPECIFICATIONS IN EUROPEAN AND INTERNATIONAL STANDARDS

\begin{tabular}{|c|c|c|c|c|c|}
\hline & $\begin{array}{l}\text { Moisture } \\
\text { (wt. } \% \text { ) }\end{array}$ & $\begin{array}{c}\text { Volatile matter } \\
\text { (wt. } \%)\end{array}$ & $\begin{array}{c}\text { Ash } \\
\text { (wt. } \%)\end{array}$ & $\begin{array}{c}\text { Calculated } \\
\text { fixed carbon (wt. } \% \text { ) }\end{array}$ & $\begin{array}{c}\text { Calorific value } \\
\left.(\mathrm{MJ} \mathrm{kg})^{-1}\right)\end{array}$ \\
\hline EFB pellets (average) & $8.16 \pm 0.50$ & $67.78 \pm 3.97$ & $7.55 \pm 4.39$ & $16.50 \pm 0.39$ & $17.04 \pm 0.81$ \\
\hline $\begin{array}{l}\text { EN 14961-2 } \\
\text { (wood - min. specs.) }\end{array}$ & $\leq 10.0$ & - & $\leq 0.3$ & - & $\geq 16.0$ \\
\hline $\begin{array}{l}\text { ISO } 17225-6 \\
\text { (non-wood) }\end{array}$ & $\leq 10.0$ & - & $\leq 10.0$ & - & $\begin{array}{l}\text { Min. value to } \\
\text { be stated }\end{array}$ \\
\hline
\end{tabular}

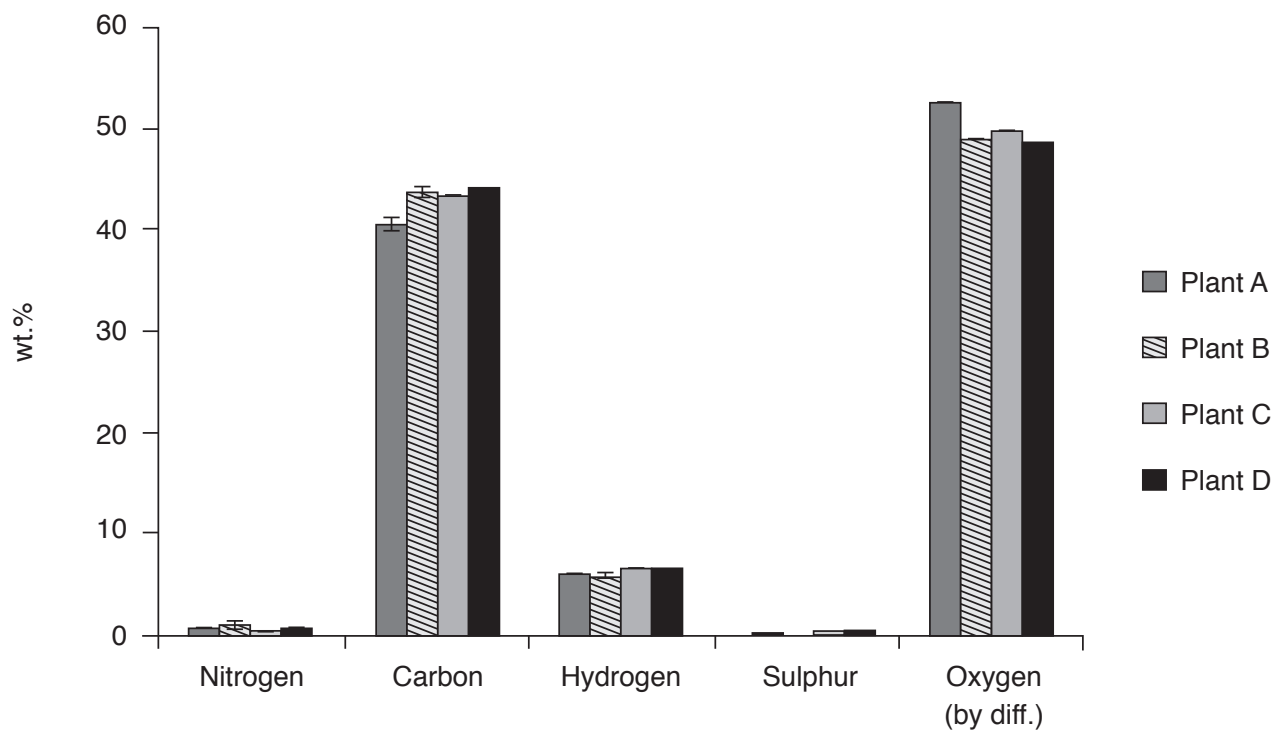

Figure 3. Ultimate analysis of empty fruit bunch (EFB) pellets. 
TABLE 4. COMPARISON OF ELEMENTAL CONTENTS OF EMPTY FRUIT BUNCH (EFB) PELLETS TO COMMERCIAL WOOD PELLETS BASED ON EUROPEAN AND INTERNATIONAL STANDARDS

\begin{tabular}{|c|c|c|c|c|}
\hline $\begin{array}{c}\text { Element } \\
(w t . \%)\end{array}$ & $\begin{array}{l}\text { EFB pellet } \\
\text { (average) }\end{array}$ & $\begin{array}{c}\text { EN 14961-2 } \\
\text { (wood) }\end{array}$ & $\begin{array}{l}\text { ISO 17225-6 } \\
\text { (non-wood) }\end{array}$ & $\begin{array}{l}\text { Wood } \\
\text { pellet }^{\mathrm{a}}\end{array}$ \\
\hline $\mathrm{C}$ & $42.99 \pm 1.68$ & - & - & - \\
\hline $\mathrm{H}$ & $6.19 \pm 0.36$ & - & - & - \\
\hline $\mathrm{N}$ & $0.64 \pm 0.30$ & $\leq 1.0$ & $\leq 2.0$ & - \\
\hline$S$ & $0.08 \pm 0.06$ & $\leq 0.05$ & $\leq 0.50$ & - \\
\hline $\mathrm{O}$ & $50.11 \pm 1.80$ & - & - & - \\
\hline $\mathrm{P}$ & $0.09 \pm 0.03$ & - & - & - \\
\hline K & $1.59 \pm 0.18$ & - & - & $0.07 \pm 0.08$ \\
\hline $\mathrm{Ca}$ & $0.43 \pm 0.15$ & - & - & $0.11 \pm 0.14$ \\
\hline $\mathrm{Mg}$ & $0.16 \pm 0.05$ & - & - & $0.02 \pm 0.02$ \\
\hline $\mathrm{Cl}$ & $0.6 \pm 0.3$ & $\leq 0.03$ & $\leq 0.50$ & $0.004 \pm 0.005$ \\
\hline
\end{tabular}

Source: a Chandrasekaran et al. (2012).

particularly K which was $>1.0$ wt. $\%$ compared to $<0.1$ wt.\% in wood-based pellets (Chandrasekaran et al., 2012). Though this element was not emphasised in the specifications of the EN 14961-2 and ISO 17225-6, its presence together with $\mathrm{S}$ and $\mathrm{Cl}$ would adversely affect biomass combustion in the furnace (fouling, slagging, corrosion) and pollutant emissions (Jenkins et al., 1998; Loh, 2017; Obernberger et al., 2006). This could hinder the export potential of EFB pellets, particularly to the developed countries.

The PD of EFB showed the mean value i.e. $96.45 \%$, which was slightly lower than the minimum requirement $(>96.50 \%)$ of $\mathrm{EN} \mathrm{14961-2}$ and ISO 17225-6 (Table 5). MC plays an important role in establishing the PD of biomass pellet. It has been reported that pellets with moisture between $8.6 \%$ to $14 \%$ could have PD between $95.9 \%$ and $96.8 \%$ which is comparable with the results obtained in this study (Theerarattananoon et al., 2011). This characteristic influences the strength and resistance of the pellets to withstand physical disintegration and impact during handling and transportation (Tumuluru, 2014). High PD reduces the possibility of pellets breaking up into pieces and dust, thereby providing easy handling and a safer and cleaner working environment for the operator.

\section{LCA Study}

The LCI (Table 6) and GHG emissions (Table 7) were established based on the inventory data collected from the four production plants. Table 6 details the type and quantity of EFB as feedstock, consumption of electricity, diesel, biomass and steam for drying purposes of the EFB feedstock. Generally, plants A, B and C used either pressed or shredded EFB as a feedstock for pellets production. The feedstock was mechanically treated at the nearby mills to reduce the size and MC before transporting to these plants. Plant D is within a palm oil mill and used raw EFB as an input for the pellets production, thus requiring the most electricity and heat (steam) for drying of the feedstock among all the plants. This implied that plant D demanded the highest amount of energy (400 $\mathrm{kWhr} \mathrm{t}^{-1}$ electricity and $3 \mathrm{t}$ steam) for the whole EFB pre-treatment which ideally could be first tapped from the existing palm oil mill biomass boiler and then the remaining from the grid. However, the plant chose to tap entirely from the grid. The diesel consumption for these production plants was relatively low, i.e. 1.0 litre $\mathrm{t}^{-1}(\mathrm{~min})$ and 3.0 litre $\mathrm{t}^{-1}$ (max) as it was mainly used internally as a forklift fuel.

On average, the electricity used for the production of $1 \mathrm{tEFB}$ pellets $\left(160-400 \mathrm{kWhr} \mathrm{t}^{-1}\right)$ was higher compared to EFB briquettes (138 $\left.\mathrm{kWhr} \mathrm{t}^{-1}\right)$ and wood pellets (132 - $145 \mathrm{kWhr} \mathrm{t}^{-1}$ ) (Reed et al., 2012; Chiew and Shimada, 2013; CORRIM, 2012). This was mainly due to an energy intensive technology used to pre-treat and improve the poor characteristics of raw EFB. The total GHG emissions of the plants varied from $0.1 \mathrm{t} \mathrm{CO}_{2} \mathrm{eq} \mathrm{t}^{-1}$ to $0.241 \mathrm{t} \mathrm{CO}_{2} \mathrm{eq} \mathrm{t}^{-1}$ of EFB pellet produced (Table 7). As expected, plant D had the highest GHG emissions due to the high electricity consumption in processing the raw EFB as a feedstock, compared to other plants which utilised the semi-treated EFB for pellets production. Although there was possibility to use renewable electricity generated from the mill to treat raw $\mathrm{EFB}$, plant D relied totally on electricity from the national grid to secure consistent and sufficient power supply. The so-called surplus energy supply by the mill was somehow limited and depending on the mill's operation hours, the availability of the biomass fuel and its power requirement. The study also showed that $>87 \%$ of the total GHG emissions was attributed to heavy consumption of electricity from the grid.

Figure 4 compares the various impact categories for the production of $1 \mathrm{t}$ EFB pellets for all the four plants. The LCIA results showed that the significant impacts ranked from major to minor as 


\begin{tabular}{|c|c|c|c|c|c|c|c|}
\hline & \multicolumn{4}{|c|}{ Source of pellet } & \multirow{2}{*}{$\begin{array}{l}\text { EFB pellet } \\
\text { (average) }\end{array}$} & \multirow{2}{*}{$\begin{array}{c}\text { EN } \\
14961-2 \\
\text { (wood) }\end{array}$} & \multirow{2}{*}{$\begin{array}{c}\text { ISO } \\
17225-6 \\
\text { (non-wood) }\end{array}$} \\
\hline & Plant A & Plant B & Plant C & Plant D & & & \\
\hline Durability, \% & $97.30 \pm 0.45$ & $97.23 \pm 0.34$ & $94.98 \pm 0.07$ & $96.30 \pm 0.20$ & $96.45 \pm 1.08$ & $>96.5$ & $>96.5$ \\
\hline
\end{tabular}

TABLE 6. LIFE CYCLE INVENTORY (LCI) OF EMPTY FRUIT BUNCH (EFB) PELLETS PRODUCTION FROM FOUR COMMERCIAL PLANTS

\begin{tabular}{|c|c|c|c|c|c|}
\hline Plant & $\begin{array}{c}\text { Type of EFB } \\
\text { feedstock }\end{array}$ & $\begin{array}{c}\text { Amount of } \\
\text { EFB feedstock } \\
\left(\mathrm{t} \mathrm{t}^{-1}\right)\end{array}$ & $\begin{array}{l}\text { Electricity } \\
\left(\mathrm{kWhr} \mathrm{t}^{-1}\right)\end{array}$ & $\begin{array}{c}\text { Diesel } \\
\left(\text { litre } \mathbf{t}^{-1}\right)\end{array}$ & $\begin{array}{l}\text { Drying } \\
\left(\mathbf{M J ~ t}^{-1}\right)\end{array}$ \\
\hline A & $\begin{array}{c}\text { Pressed and } \\
\text { short EFB fibre }\end{array}$ & $2.22 \pm 0.21$ & $250.0 \pm 10.0$ & $3.0 \pm 0.5$ & 401.3 \\
\hline B & Shredded EFB & $2.33 \pm 0.15$ & $210.0 \pm 10.0$ & $2.9 \pm 0.3$ & 501.6 \\
\hline $\mathrm{C}$ & Pressed EFB & $2.35 \pm 0.25$ & $160.0 \pm 5.0$ & $2.0 \pm 0.5$ & 525.0 \\
\hline $\mathrm{D}$ & Raw EFB & $4.50 \pm 0.8$ & $400.0 \pm 20.0$ & $1.0 \pm 0.2$ & $\begin{array}{c}1752 \\
(3.0 \mathrm{t} \text { of steam })\end{array}$ \\
\hline Average & - & $2.85 \pm 1.10$ & $265.0 \pm 103.44$ & $2.25 \pm 0.93$ & $795.00 \pm 640.27$ \\
\hline
\end{tabular}

TABLE 7. GREENHOUSE GAS (GHG) EMISSIONS OF EMPTY FRUIT BUNCH (EFB) PELLETS PRODUCTION PLANTS

\begin{tabular}{cccc}
\hline Plant & $\begin{array}{r}\text { GHG, electricity used } \\
\left(\mathbf{t ~ C O}_{\mathbf{2}} \mathbf{e q ~} \mathbf{~ t}^{-1}\right)\end{array}$ & $\begin{array}{r}\text { GHG, diesel used } \\
\left(\mathbf{t ~ C O}_{\mathbf{2}} \mathbf{e q ~} \mathbf{~ t}^{-1}\right)\end{array}$ & $\begin{array}{c}\text { Total GHG } \\
\left(\mathbf{t ~ C O}_{2} \mathbf{e q ~}^{-1}\right)\end{array}$ \\
\hline $\mathrm{A}$ & 0.149 & 0.008 & 0.157 \\
$\mathrm{~B}$ & 0.125 & 0.008 & 0.133 \\
$\mathrm{C}$ & 0.095 & 0.005 & 0.100 \\
$\mathrm{D}$ & 0.238 & 0.003 & 0.241 \\
\hline
\end{tabular}

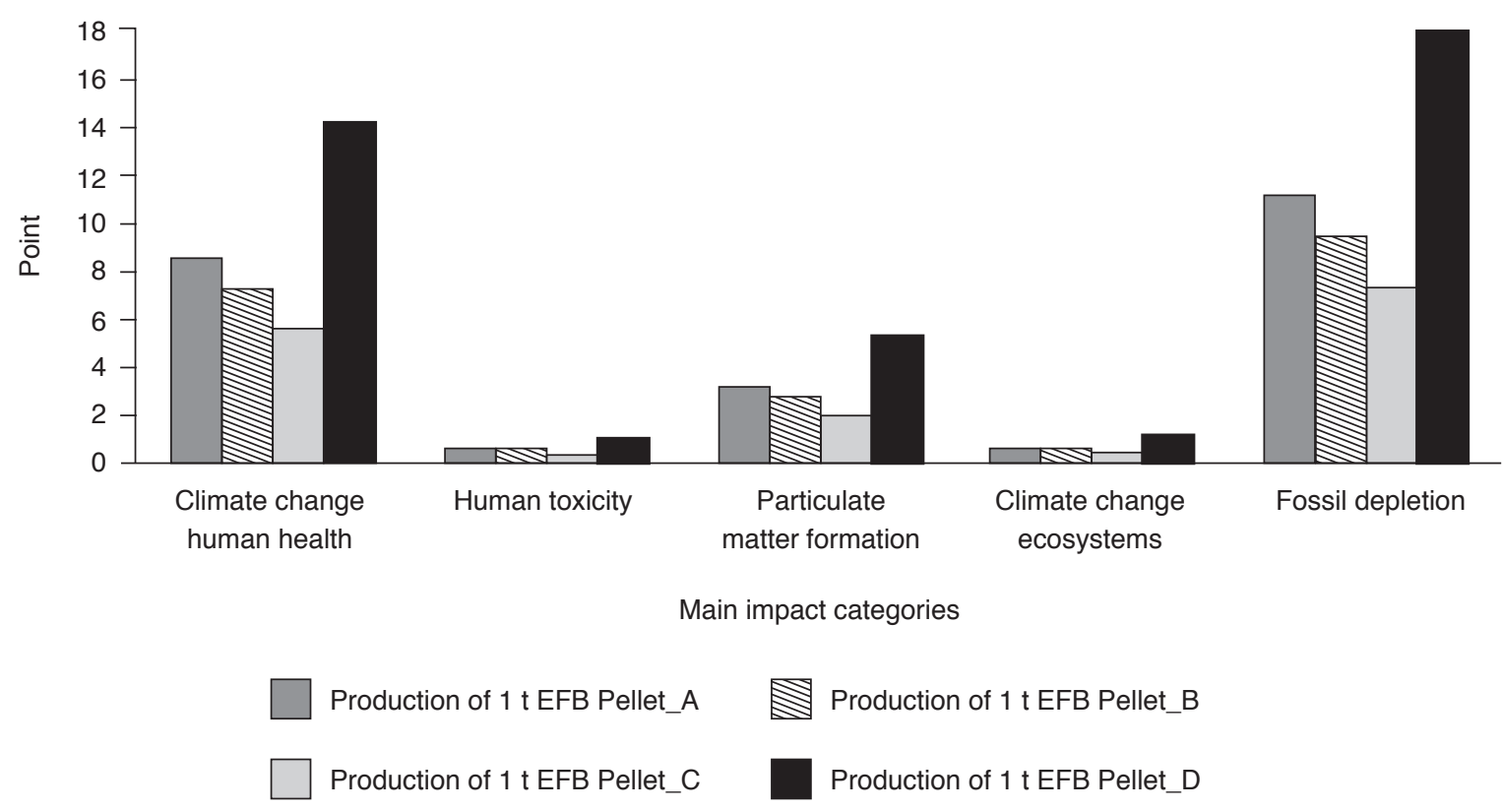

Figure 4. Life Cycle Impact Assessment for the production of empty fruit bunch (EFB) pellets. 
follows: fossil depletion $>$ climate change human health $>$ particulate matter $>$ climate change ecosystem $>$ human toxicity. This was due to the heavy dependence and consumption of ongrid electricity and diesel for pellets production at all the plants. Nevertheless, the potential of the resulting EFB pellets as solid biofuel would provide a net benefit on the energy balance along the supply chain by offsetting the fossil-based energy required to produce pellets (Reed et al., 2012).

It has been reported that the technology for the production of solid biofuel from EFB has a lower impact in most of the impact categories compared to other palm-based biofuel technologies such as those for the production of biogas, combined heat and power (CHP) and bioethanol when assessed using the CML2 baseline (200) methodology (Chiew and Shimada, 2013). The environmental impact of EFB pellets production is mainly due to the high consumption of on-grid electricity and this can be reduced by using electricity efficiently, or better still, by tapping renewable electricity generated from available CHP or biogas plants (Mahalle, 2013).

\section{CONCLUSION}

This study showed that the commercial EFB pellets fuel properties were comparable to the minimum specifications of the EN 14961-2 (for wood pellet) except for the higher ash, $\mathrm{S}$ and $\mathrm{Cl}$ contents. $\mathrm{Cl}$ content was the only parameter which exceeded the requirement of ISO 17225-6. Therefore, the information collected from this investigation on EFB pellet fuel can be used as a reference for standard development, commercial exploitation or the designing of biomass energy conversion system. As it was found that the environmental impact resulting from the production of EFB pellets was mainly due to the heavy consumption of fossil fuels, a more efficient utilisation of the fossil-based (grid) electricity and its displacement by renewable fuels could be explored. The findings of this study can be used for expanding the scope of the LCA study of oil palm biomass pellets, e.g. cradle-togate assessment. This will ensure that sufficient information is available to mitigate potential adverse environmental impacts in the stages of the value chain production of EFB pellets.

\section{ACKNOWLEDGEMENT}

The authors thank the Director-General of MPOB for permission to publish this article. Thanks are also due to all individuals, industrial partners, EFB pellet producers and technology providers who were directly or indirectly involved in this study.

\section{REFERENCES}

ACDA, M and DEVERA, E (2014). Physico-chemical properties of wood pellets from forest residues. $J$. Tropical Forest Science, 26 (4): 589-595.

\section{CONSORTIUM FOR RESEARCHON RENEWABLE} INDUSTRIAL MATERIALS (CORRIM) (2012). CORRIM special session: biofuel environmental performance. Forest Product Society $66^{\text {th }}$ International Convention. Washington DC, USA.

CHANDRASEKARAN, $\mathrm{S} \mathrm{R}$; HOPKE, $\mathrm{P} \mathrm{K}$; RECTOR, L; ALLEN, G and LIN, L (2012). Chemical composition of wood chips and wood pellets. Energy E Fuels, 26: 4932-4937.

CHIEW, Y L and SHIMADA, S (2013). Current state and environmental impact assessment for utilizing oil palm empty fruit bunches for fuel, fiber and fertilizer - a case study of Malaysia. Biomass and Bioenergy, 51: 109-124.

CHIN, K; H'NG, P; CHAI, E; TEY, B; CHIN, M; PARIDAH, M; LUQMAN, A and MAMINSKI, M (2013). Fuel characteristics of solid biofuel derived from oil palm biomass and fast growing timber species in Malaysia. Bioenergy Research, 6: 75-82.

ERLICH, C and FRANSSON, T H (2011). Downdraft gasification of pellets made of wood, palm-oil residues respective bagasse: experimental study. Applied Energy, 88: 899-908.

IEA (2016). www.iea.org / topics / renewables / subtopics/bioenergy, accessed in August 2016.

JENKINS, B; BAXTER, L and MILES, T (1998). Combustion properties of biomass. Fuel Processing Technology, 54: 17-46.

KONG, S H; LOH, S K; BACHMANN, R T; RAHIM, $S$ A and SALIMON, J (2014). Biochar from oil palm biomass: a review of its potential and challenges. Renewable and Sustainable Energy Reviews, 39: 729739.

KYLILI, A; CHRISTOFOROU, E and FOKAIDES, P A (2016). Environmental evaluation of biomass pelleting using life cycle assessment. Biomass and Bioenergy, 84: 107-117.

LAM, P Y; LIM, C J; SOKHANSANJ, S; LAM, P S; STEPHEN, J D; PRIBOWO, A and MABEE, W E (2014). Leaching characteristics of inorganic constituents from oil palm residues by water. Industrial and Engineering Chemistry Research, 53: 11822-11827. 
LOH, S K (2017). The potential of the Malaysian oil palm biomass as a renewable energy source. Energy Convers Manage., 141: 285-298.

MAGELLI, F; BOUCHER, K; BI, H T; MELIN, S and BONOLI, A (2009). An environmental impact assessment of exported wood pellets from Canada to Europe. Biomass and Bioenergy, 33: 434-441.

MAHALLE, L (2013). Comparative life cycle assessment of pellet, natural gas and heavy fuel oil as heat energy sources. Natural Resources Canada. Ottawa.

MATTHEWS, F (2015). Global wood pellet market outlook. WPAC Annual Conference. Halifax, Canada.

MCKENDRY, P (2002). Energy production from biomass (part 1): overview of biomass. Bioresources Technology, 83: 37-46.

MITCHELL, E J S; LEA-LANGTONA, A R; JONES, J M; WILLIAMS, A A; LAYDEN, P and JOHNSON, $R$ (2016). The impact of fuel properties on the emissions from the combustion of biomass and other solid fuels in a fixed bed domestic stove. Fuel Processing Technology, 142: 115-123.

MPOB (2017). http://bepi.mpob.gov.my/index. $\mathrm{php} / \mathrm{en} /$ statistics / sectoral-status / 170-sectoralstatus-2016/755-ffb-processed-by-mill-2016.html, accessed in January 2017.

MUNAWAR, S S and SUBIYANTO, B (2014). Characterization of biomass pellet made from solid waste oil palm industry. Procedia Environmental Sciences, 20: 336-341.

MURRAY, G (2016). Emerging pellet markets in Asia. Western Forest Industry Conference. Vancouver, Canada.

NUNEZ, C A F; JOCHUM, J and VARGAS, F E S (2012). Characterization and feasibility of biomass fuel pellets made of Colombian timber, coconut and oil palm residues regarding European Standards. Environmental Biotechnology, 8: 67-76.
OBERNBERGER, I; BRUNNER, T and BÄRNTHALER, G (2006). Chemical properties of solid biofuels - significance and impact. Biomass and Bioenergy, 30: 973-982.

RAHMAN, N A; ATAN, M; LOW, C; BAINI, R; MAT, N C and SALLEH, S (2013). Study on the potential of pelletisation of empty fruit bunch with sago as binding agent for power generation. European International J. Science and Technology, 2: 11-118.

REED, D; BERGMAN, R; KIM, J W; TAYLOR, A; HARPER, D; JONES, D; KNOWLES, C and PUETTMANN, M E (2012). Cradle-to-gate lifecycle inventory and impact assessment of wood fuel pellet manufacturing from hardwood flooring residues in the south-eastern United States. Forest Products J., 62: 280-288.

STELTE, W; HOLM, J K; SANADI, A R; BARSBERG, S; AHRENFELDT, J and HENRIKSEN, U B (2011). Fuel pellets from biomass: the importance of the pelletizing pressure and its dependency on the processing conditions. Fuel, 90: 3285-3290.

THEERARATTANANOON, K; XU, F; WILSON, J; BALLARD, R; MCKINNEY, L; STAGGENBORG, S; VADLANI, P; PEI, Z and WANG, D (2011). Physical properties of pellets made from sorghum stalk, corn stover, wheat straw, and big bluestem. Industrial Crops and Products, 33: 325-332.

TUMULURU, J S (2014). Effect of process variables on the density and durability of the pellets made from high moisture corn stover. Biosystems Engineering, 119: 44-57.

VIJAYA, S; MA, A N and CHOO, Y M (2010). Capturing biogas: a means to reduce greenhouse gas emissions for the production of crude palm oil. American J. Geoscience, 1: 1-6.

VIJAYA, S; MA, A N; CHOO, Y M and NIK MERIAM, $\mathrm{N}$ (2008). Life cycle inventory of the production of crude palm oil - a gate to gate case study of 12 palm oil mills. J. Oil Palm Res. Vol. 20: 484-494.

WALKER, S (2014). Global pellet market update: Canadian perspective. WPAC Conference. Vancouver, Canada. 